\title{
The Development of Shariah Risk Management Model (SRM-i) for the Use of Shariah Compliance Organizations
}

\author{
Mohd Helmi Ahmad', Najahudin Lateh² \\ ${ }^{1}$ Chief Executive Officer, SCR Strategic \& Advisory Sdn Bhd, Shah Alam, Malaysia. \\ 2 Senior Lecturer at Academy of Contemporary Islamic Studies (ACiS), UiTM, Shah Alam
}

scr.mhelmi73@gmail.com, najahudin@uitm.edu.my

\begin{abstract}
Shariah Governance Framework (SGF) has become the important essence in Islamic Financial Service Act (IFSA 2013) or Act 759. However, from the professional observation, as well as the Shariah auditor, the researchers found the lack of pure Shariah risk management as well as the qualified Shariah risk officers (SRO) in Shariah Compliance Organizations (SBO). This is not acceptable because Shariah risk has its unique criteria and terminologies. For that, SBO and Islamic Finance Institutions (IFIs) need to develop a pure Shariah Risk Management model (SRM-i) for their use.
\end{abstract}

Keywords: Shariah risk, Shariah risk model, SRM-i, rectification plan

eISSN: 2398-4287 @ 2020. The Authors. Published for AMER ABRA cE-Bs by e-International Publishing House, Ltd., UK. This is an open access article under the CC BYNC-ND license (http://creativecommons.org/licenses/by-nc-nd/4.0/). Peer-review under responsibility of AMER (Association of Malaysian Environment-Behaviour Researchers), ABRA (Association of Behavioural Researchers on Asians) and cE-Bs (Centre for Environment-Behaviour Studies), Faculty of Architecture, Planning \& Surveying, Universiti Teknologi MARA, Malaysia.

DOI: https://doi.org/10.21834/ebpj.v5iSI1.2301

\subsection{Introduction}

Risk is made known to everyone as a hazard, loss of opportunity, loss of income, and loss of life. Risk management is a very much important discipline and knowledge that should be useful to someone. From Muslim personal matters until the national governance, the risk has become the meat of it. There shall be the dos' and don'ts in almost everything purposely to secure the benefit and to avoid any unexpected outcomes. Whether everyone is aware of it or not, it has become a daily task to avoid or secure the risk. Meanwhile, a risk itself can be divided into two categories which are (i) positive risk and (ii) negative risk. Positive risk is always the favorable whilst negative risk is otherwise. As being mentioned before, risk management could be the top priority of Islamic teachings which there are a lot of prohibitions restricting Muslims from doing so.

For example, the positive risk can be found in Halal items whilst the negative risk in the Haram items. Al Qaradawi described that the prohibition is much attended in Quranic verses and Islamic teaching which if someone is not aware of it, it could cause him to fall under the restricted areas and the boundaries set by Allah. Therefore, the Halal things can upraise people's level towards becoming the pious person and on the contrary, it could put them in a despicable place (Qaradawy, 2012). This is the real value of risk management related to our daily life and activity.

This paper will give a glance at Shariah risk-based audit outcomes which took place in 2014 until 2017. The author himself is an auditor together with his team, which the audit findings will require the company to rectify the issue of inadequacy in the Shariah risk management framework and matrix. This is deemed as important to avoid inaccurate Shariah rulings and decisions made by the internal Shariah advisors, resulted from that incorrect risk matrix and measurement. For example, the company has a situation to deploy an ATM in front of an amusement area and the risk management will measure whether it would be something restricted or not to the company.

We found that there is a decision made by one of the organizations which restricting the company from deploying the ATM because of the concern if the money is withdrawn, which will lead to the non-compliant activity such as leisure activities, drinking alcohol, etc. At the same time, we explored that its written meeting minutes noted some Shariah committee members allowed it with the excuse of the

eISSN: 2398-4287 ( 2020. The Authors. Published for AMER ABRA cE-Bs by e-International Publishing House, Ltd., UK. This is an open access article under the CC BYNC-ND license (http://creativecommons.org/licenses/by-nc-nd/4.0/). Peer-review under responsibility of AMER (Association of Malaysian Environment-Behaviour Researchers), ABRA (Association of Behavioural Researchers on Asians) and cE-Bs (Centre for Environment-Behaviour Studies), Faculty of Architecture, Planning \& Surveying, Universiti Teknologi MARA, Malaysia.

DOI: https://doi.org/10.21834/ebpj.v5iSI1.2301 
money belong to the customers and it is up to them to do what they desire. A few Shariah shreds of evidence have been cited during the meeting as to encompass the matters and issues raised. This will also lead to minor disputes and sometimes into inconsistent ruling within the same organization. Why is this happening? During the investigation that the auditor conducted, it is found that there is no uniformity in terms of decision making especially where and when to reject the risk or to accept it. This will lead to a lengthy discussion in the absence of a proper and sound term of reference in risk management especially Shariah rejected risk. It has come the auditor's attention to propose the measure that can rectify the inconsistency of the rulings made by the SC, and subsequently by the management.

Humans are accountable for every action done by them. In the Holy Quran, a lot of verses saying about the hisbah, muhasabah, etc. These refer to the importance of the audit (Shahul Hameed, 2012). That is why we need to uniform the system and the method to avoid any unexpected event in Shariah governance.

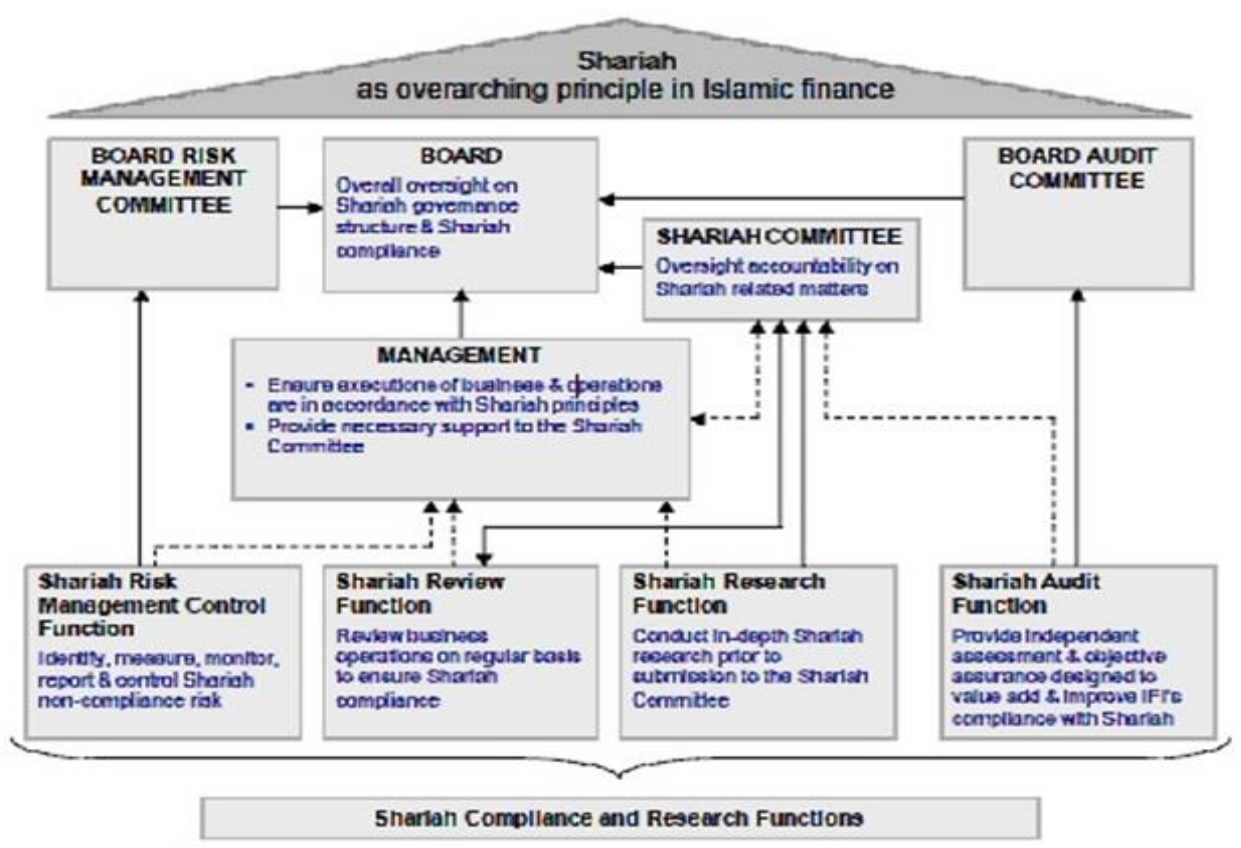

Figure 1. Shariah Governance reporting lines.

To begin with, there is a Shariah risk-based audit. It is performed when it is necessary to do a surveillance auditing to find out the level of compliance or if there was an incident took place which requires a necessary action and remedy to be taken in a short period. Every audit has its post-implementation. If there was a finding and it was rated as a high impact, then it is certainly needed to conduct a particular audit to investigate the root cause which is also called forensic audit of Shariah non-compliance risk (SNCR). BNM, in its Shariah Governance Framework, specifies the functionality of Shariah audit and Shariah risk (BNM, 2011). Both are co-existed and deemed as important to realize proper and sound Shariah governance in the financial institutions. It plays the same role and meaning on the other side of Shariah-compliant institutions such as a certified MS1900:2015 or ISO9001:2015.

The researchers have decided to use the Shariah audit input and to gather text analysis data besides reviewing the industry's practice before finally came out with the results. It went through a few processes such as identifying the gaps (if any) and running a simulation via Nominal Group Technique (NGT) to conclude what is the ideal matrix that can be used for Shariah risk assessment. The processes are shown in the following diagram

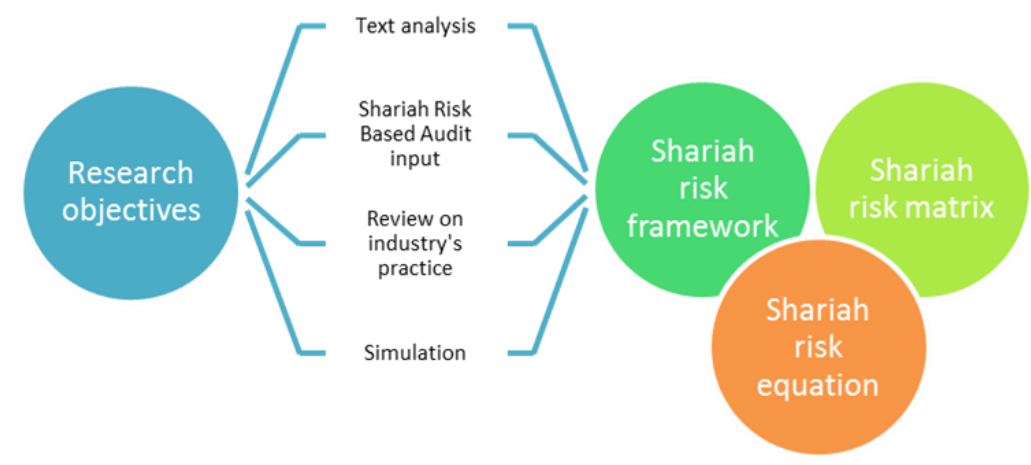

Figure 2. Research framework and processes. 
Later, the process of the audit is simplified using the following diagram:

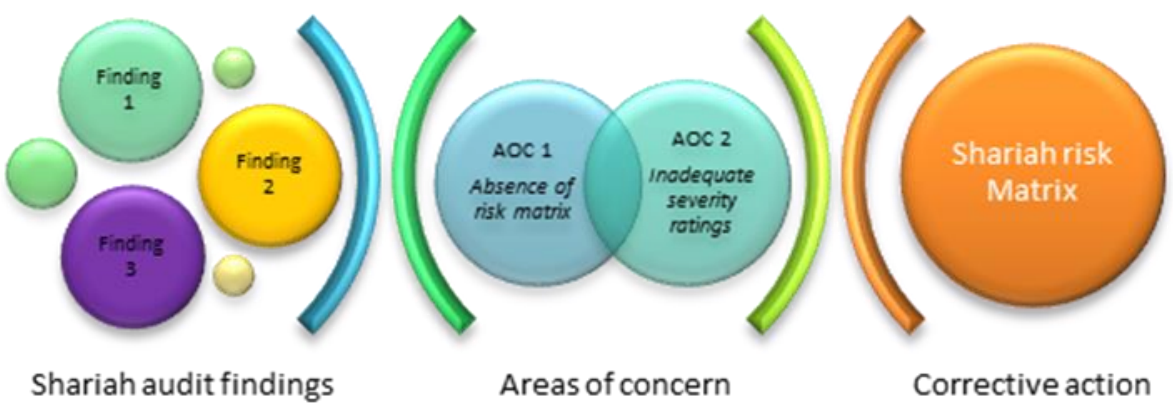

Figure 3. Shariah Audit plan took place.

The objectives of this audit or Shariah risk-based audit are;

1) to examine and evaluate the extent of compliance with Islamic Shariah rules and principles, fatwas, guidelines, and instructions issued by the $\mathrm{IFI}(\mathrm{s})$ Shariah committee.

2) to ensure that the management of $\mathrm{IFI}(\mathrm{s})$ discharge their responsibilities concerning the implementation of the Shariah rules and principles as determined by the IFI(s) Shariah committee.

From the text analysis, we found that risk management was first invented in western countries such as United States, Australia, New Zealand, etc. Gjerdrum (2015) mentions that the first risk management standard recognized, ISO 31000, (published in the United States as ISO/ANSI/ASSE 31000) is the only international standard for the practice of risk management. Earlier, Kuhn (1998) states that risk management is 'the identification, assessment, and prioritization of risks and (defined in ISO 31000 as the effect of uncertainty on objectives) followed by coordinated and economical application of resources to minimize, monitor, and control the probability and/or impact of unfortunate events or to maximize the realization of opportunities. Meanwhile, the IIA (Institute of Internal Auditors Malaysia) defines risk as "the possibility of an event occurring that will have an impact on the achievement of objectives". The risk is measured in terms of an impact and a likelihood (Florea, (2016).

To summarize, risk management is a process and an exercise of identification, assessment, and prioritization of risks followed by coordinated and economical application of resources to minimize, monitor, and control the probability and impact of unfortunate events or to maximize the profitability of the organization towards its functions.

\subsection{Method}

To verify the research questions, we have to examine the necessary Shariah evidence, starting from Quranic verses to Hadith and then the relevant Shariah evidence. We also set a survey form and distributed it to several Shariah advisors and practitioners in the industry to measure the level of Shariah risk understanding among them and to find out whether the Shariah risk principle exists or not in the environment. We found that there is an agreement among them that Shariah risk management is a part of Shariah indeed. When it comes to Halal and Haram itself, it shows that Shariah has its limitation on the guidelines provided. This is an example of risk management and it is considered as Shariah risk as well as the main source of Shariah risk management principles.

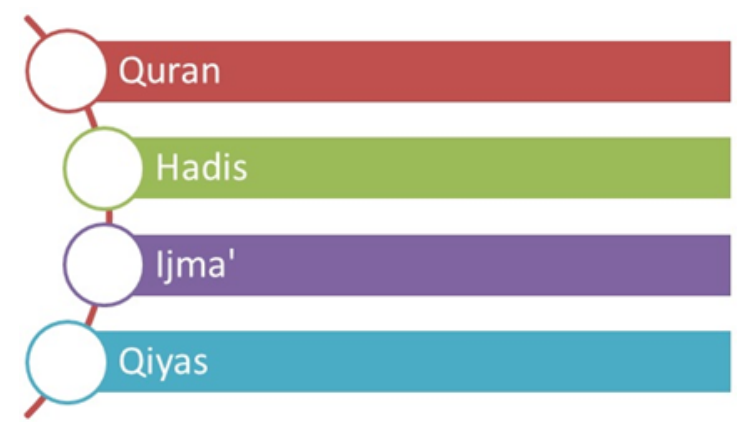

Figure 4. Source of Shariah risk management principles.

We took the sample of 13 Quranic verses and another 5 hadiths and we found that Shariah evidence fully supports that risk management was originated from Islamic teachings. No matter what other authors will say, we can affirm that $100 \%$ of Islamic manuscripts contain the element of commands and prohibitions which the essence of risk management itself. 
Table 1. Examples of the Shariah risk management principle abstracted from Quranic verses.

\begin{tabular}{|c|c|c|c|c|c|c|}
\hline $\begin{array}{c}\text { Possible risk } \\
\text { inquacts }\end{array}$ & $\begin{array}{l}\text { Shariah } \\
\text { objecaives }\end{array}$ & Type ofverse & Code & $\begin{array}{l}\text { Number } \\
\text { orverse }\end{array}$ & Quanic versss & Ref. \\
\hline $\begin{array}{l}\text { 1. Survival. } \\
\text { 2. Regulatory. } \\
\text { 3. System. } \\
\text { 4. Financial. } \\
\text { 5. Repuation. }\end{array}$ & $\begin{array}{l}\text { 1. Life. } \\
\text { 2. Re ligious. } \\
\text { 3. Mind. } \\
\text { 4.Property. } \\
\text { 5.Dignity. }\end{array}$ & $\begin{array}{l}\text { This verse is in } \\
\text { form of story } \\
\text { telling bot } \\
\text { encompass a } \\
\text { prohibition } \\
\text { from causing a } \\
\text { disaster where } \\
\text { the } \\
\text { consequences } \\
\text { will certainly } \\
\text { occurs onto } \\
\text { themself. }\end{array}$ & $\begin{array}{l}\text { Prohibition } \\
\text { (P) }\end{array}$ & $30: 41$ & & 1 \\
\hline $\begin{array}{l}\text { 1. Regulatory. } \\
\text { 2. Financial. } \\
\text { 3. Reputation. }\end{array}$ & $\begin{array}{l}\text { 1. Religious. } \\
\text { 2. Property. } \\
\text { 3. Dignity. }\end{array}$ & $\begin{array}{l}\text { This verse } \\
\text { ind ixates the } \\
\text { prohibition } \\
\text { from aking the } \\
\text { other's except } \\
\text { trough trades } \\
\text { and muamalat. }\end{array}$ & (P) & 429 & & 2 \\
\hline $\begin{array}{l}\text { 1. Regulatory. } \\
\text { 2. Financial. } \\
\text { 3. Reputation. }\end{array}$ & $\begin{array}{l}\text { 1. Re Ligious. } \\
\text { 2. Property. } \\
\text { 3. Dignity. }\end{array}$ & $\begin{array}{l}\text { This verse } \\
\text { came to remind } \\
\text { the believers } \\
\text { from extremely } \\
\text { loving their } \\
\text { properties and } \\
\text { families } \\
\text { besides } \\
\text { remembering } \\
\text { Allah. }\end{array}$ & $\mathrm{p}$ & 639 & , & 3 \\
\hline $\begin{array}{l}\text { 1. Survival. } \\
\text { 2. Regulatory. } \\
\text { 3. Financial. } \\
\text { 4. Repuation.. }\end{array}$ & $\begin{array}{l}\text { 1. Life. } \\
\text { 2. Religious. } \\
\text { 3. Property. } \\
\text { 4. Dignity. }\end{array}$ & $\begin{array}{l}\text { This verse ask } \\
\text { the Muslim to } \\
\text { contribute their } \\
\text { mories in a } \\
\text { way of Allah } \\
\text { and avoid } \\
\text { destruct their } \\
\text { property } \\
\text { without } \\
\text { reasonable } \\
\text { cause. }\end{array}$ & $\begin{array}{l}\text { Command } \\
\text { (C) }\end{array}$ & $2: 195$ & 3 & 4 \\
\hline
\end{tabular}

Shariah risk management is an established framework and function since the revelation of Islam in its early stage. After the evolution of human practice and the expanding of the geographical border among Islamic states, Shariah risk management has since experienced an evolution as well (Helmi, 2013).

At this point, we can confidently say that risk management was originated from the wahyu and Islamic revelation. It was the first and most important Islamic teaching. Nevertheless, the role of modern risk management is still applicable as long as it is in line with the Shariah principles.

Hence, Shariah risk management is not a new brainchild by anyone in this modern world after all and it is not an adoption from modern risk management. It was inherited from the first revelation of revelation to mankind. All the previous prophets came to this world to protect the main objective of their existence that can be formulated into five (5) following important Shariah objectives.

Every Shariah-compliant organization (SCO) shall establish their own and unique risk management framework. On the other hand, ignoring Shariah risk management and its necessary elements can lead to the following Shariah non-compliance residuals and effects:
(a) Impediment from Allah's blessing
(b) Against the command of Allah
(c) Tarnish business reputation
(d) Involves in invalid contracts
(e) Involves in non-halal income
(f) Potential cancelation of business entity and registration (license)
(g) Imposed the monetary penalty by the regulator 


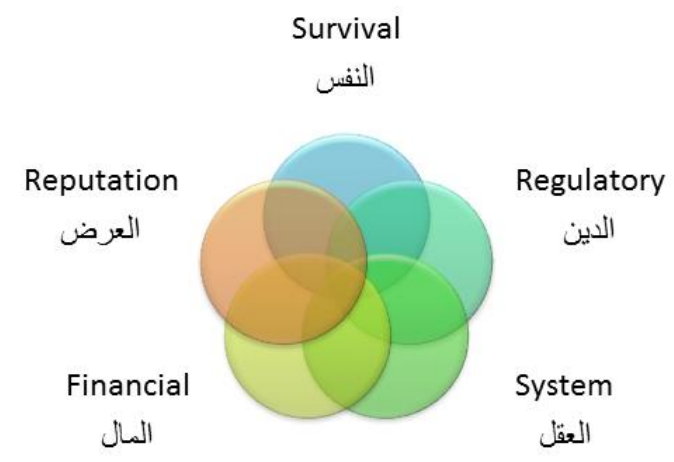

Figure 6. Shariah risk management objectives.

\subsection{Result and Discussion}

Until at this point of discussion, we can conclude that Shariah audit and Shariah risk are important elements in the SGF regardless of the type of the organization. Both have organic bonding which cannot be broken apart. This explains how the Shariah audit plays a significant role in improving and enhancing Shariah risk management in the organization. After the evolution of human practice and the expanding the geographical border among Islamic states, Shariah risk management has encountered an evolution as well (Helmi, 2013).

Risk management has a few components and elements which are as follows;
1) Risk category.
2) Risk rating.
3) Severity/Vulnerability.
4) Probability.
5) Frequency.
6) Risk impact.
7) Risk equation.
8) Risk value.

Risk value is the ultimate point for the risk monitoring process. It indicates the level of risk and the potential impact of any incident. Risk value also indicates the required measure in the interval phase of either to eliminate, reduce, control, or transfer the risk. Hence, the risk coordinator can decide either to accept or to avoid and reject the risk.

By having a value in hand, every manager can determine the probability of each business decision and what is a necessary measure to be taken in the event of a regulatory breach, financial loss, security breach, etc. This will ensure that the business can continue and secure the investor interest by making expected profits and to avoid any financial losses. The risk is calculated using the following formula:

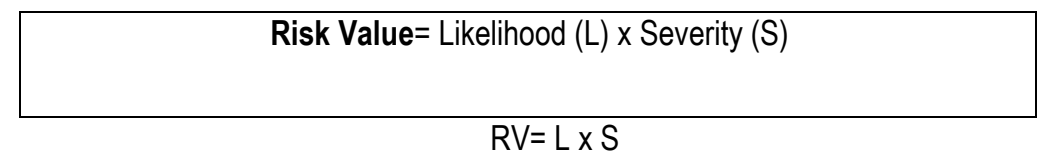

\subsection{Conclusion}

Shariah risk-based Management Model is important and required by most of the Shariah-based organization which acquired MS1900:2015 or ISO9001:2015. The model itself defined as a periodical assessment conducted from time to time to ensure the organization in a state of good governance in terms of its survival, financial risk-free, reputational risk-free, and most of all, regulatory risk-free. To do that, it has to done by an independent assessment designed to add value and improve the degree of compliance about the Shariah-based business operations mainly and to Islamic Finance Institutions specifically, with the main objective of ensuring a sound and effective internal control system to achieve the organisation objectives. Bear in mind that Shariah risk management is an established framework and function since the revelation of Islam on its early stage, i.e. during the time Prophet Yusof a.s. The SBO must develop, identify, furnish, and execute the proper plan and sound SRM-i throughout their annual business and strategic plan. For some organization which applying external certification body such as Halal certification, ISO 9001:2015, MS1900:2016 certification, and many others, they have to execute at least once Shariah risk assessment for each quarterly business calendar. It can be good as the normal compliance audit and sometimes it can be a surveillance and re-certification audit. Same thing with the Shariah risk assessment and management. By doing this, it can develop the Shariah risk management model which equitable and for some reason, help the organization for better performance. 


\section{Acknowledgments}

We hereby like to appreciate and thank UiTM especially the supervisor for his pieces of advices along with this research. Not to forget, the information provided by SCR Strategic \& Advisory Sdn Bhd, as the audit firm and PSV International Sdn Bhd, and we took the non-disclosure agreement as what it takes.

\section{References}

Al-Quran. Ibn Majah, I. M. b. Y. I. M. a.-Q. Sunan Ibn Majah. Book, 37 volumes.

Abror, M. (2012). Halal dan Haram di dalam Islam mengikut Imam al Ghazali. Thesis(Institut Agama Islam Negeri Sunan Ampel Surabaya), 1.

BNM. (2011). SHARIAH GOVERNANCE FRAMEWORK. BNM Guidelines(2), 50.

BNM. (2013). Act 759. PU(B) 277/2013(18 Mar 2013), 187.

Lorea, R., \& Florea, R. (2016). Internal audit and risk management. ISO 31000 and ERM approach. Economy Transdisciplinary Cognition, 19(1) (72-77).

Ghazali, a. (1993). Al Mustasfa. Book, 1(1), 392.

Ghazali, a. (-). Ihya Ulum al'Din. [lhya Ulum al ‘Din]. Book, 1(1), 192.

Gjerdrum, D. (2015). Risk Management's Standard of Practice - An Overview of ISO 31000. ARM-P Gallagher Public Sector Gallagher ERM Practice Group.

Helmi, M. (2013). Shariah Compliance risk Framework for Takaful Operators: An Introduction. Spekki 2013, University Malaya, 9.

ISRA. (2009). ISRA Thematic Workshop (ITW). Managing Shariah Risk through Shariah Governance.

Kuhn, A. M. (1998). Introduction to Risk Management. The Risk Manager s Desk Reference. 2nd ed. Maryland: Aspen Publishers, 1-4.

Qaradawy, P. D. Y. A. (2012). Halal dan Haram di dalam Islam, الا سلام ف ي و ال حر ام الـ حلال. (Maktabah Wahbah, Beirut).

Shahul Hameed, A. L., Datuk Syed Othman AI Habshi. (2012). Shariah Audit: Evidence \& Methodology in Islamic Finance. INCEIF Centre for Islamic Wealth Management (CIWM), 24.

Helmi, M. (2013). Shariah Compliance risk Framework for Takaful Operators: An Introduction. Spekki 2013, University Malaya, 9.

Hong Leong MSIG Takaful Berhad, H. (2013). RISK MANAGEMENT ACCORDING TO SHARIAH. Shariah training slides, 1, 20.

Lahsasna, A. (2014). Fundamental Concept of Shariah and Shariah Non-Compliance Risk. In Shariah Non-Compliance Risk Management and Legal Documentation in Islamic Finance (pp. 5-27): John Wiley \& Sons Singapore Pte. Ltd.

Nazri, M. (2013). Shariah Governance Framework-Shariah Risk Management. Proceeding Asia Islamic Banking Conference(4th), 25.

Salamon, S. (2016). HOW OFTEN ARE INTERNAL AUDITS NEEDED FOR YOUR ORGANIZATION. I.S. partners.

SCR Strategic \& Advisory Sdn Bhd (SCR), M. H. (2017). Quality Manual. The procedure, 24. 